удК 338.22.021.2

\title{
МЕХАНІЗМИ РОЗВИТКУ ЕКОНОМІКИ УКРАЇНИ В СУЧАСНИХ УМОВАХ
}

\section{MECHANISMS FOR THE DEVELOPMENT OF THE UKRAINIAN ECONOMY IN MODERN CONDITIONS}

\author{
Клочко Віталій Миколайович \\ кандидат економічних наук, доцент, \\ Харківський торговельно-економічний коледж \\ Київського національного торговельно-економічного університету \\ ORCID: https://orcid.org/0000-0003-4100-1838 \\ Постольна Наталія Олександрівна \\ викладач, \\ Харківський торговельно-економічний коледж \\ Київського національного торговельно-економічного університету \\ ORCID: https://orcid.org/0000-0002-7283-5870
}

Klochko Vitaliy, Postolna Natalia

Kharkiv Trade and Economic College of

Kiev National Trade and Economic University

\begin{abstract}
Стаття присвячена актуальним механізмам розвитку економіки України в сучасних умовах. Наведено прогнози на майбутнє від датського Saxo Bank, журнала The Economist, газети Financial Times, німецького економіста Клауса Швабба та італійського публіциста Мауріціо Блонде. Проаналізовано огляд циорової трансфрормації Microsoft CEE 2020 «Ключові галузі еволюції. Як інтелектуальні технології змінюють роздрібну торгівлю, виробництво і фрінанси в Центральній і Східній Європі». Досліджено структуру видаткової частини Державного бюджету України за період 2014-2021 рр. Систематизовано дослідження щодо нового шостого технологічного укладу. Окреслено проблеми в українській економіці, що вимагають усунення в ситуації світової економічної кризи. Запропонований механізм надання дешевих кредитів виробничій сорері та Стратегія приватно-державного партнерства в Україні.
\end{abstract}

Ключові слова: прогноз, трансформація, механізм, економіка, розвиток, проблеми, стратегія.

Статья посвящена актуальным механизмам развития экономики Украины в современных условиях. Приведены прогнозы на будущее от датского Saxo Bank, журнала The Economist, газеты Financial Times, немецкого экономиста Клауса Швабба и итальянского публициста Маурицио Блонде. Проанализированы обзор цисровой транссормации Microsoft CEE 2020 «Ключевые отрасли эволюции. Как интеллектуальные технологии меняют розничную торговлю, производство и фринансы в Центральной и Восточной Европе». Исследована структура расходной части Государственного бюджета Украины за период 2014-2021 гг. Систематизированы исследования относительно нового шестого технологического уклада. Обозначены проблемы в украинской экономике, требующие устранения в ситуации мирового экономического кризиса. Предложен механизм предоставления дешевых кредитов производственной сфере и Стратегия частно-государственного партнерства в Украине.

Ключевые слова: прогноз, трансформация, механизм, экономика, развитие, проблемы, стратегия.

The relevance of solving the problems of economic growth and investment self-sufficiency becomes extremely important in the current crisis conditions. The main objectives of the article are to study current forecasts for the development of the world economy, the budget of Ukraine for 2021 and substantiate the mechanisms for the further development of the Ukrainian economy in modern conditions. The article is devoted to the actual mechanisms of development of the Ukrainian economy in modern conditions. Forecasts for the future from the Danish Saxo Bank, The Economist magazine, the Financial Times, the German economist Klaus Schwabb and the Italian publicist Maurizio Blonde. The review of digital transformation Microsoft CEE 2020 "Key industries of evolution. How smart technologies are changing retail, manufacturing and finance in Central and Eastern Europe. The structure of the expenditure side of the State budget of Ukraine for the period 2014-2021 has been investigated. Research on a 
new sixth technological order is systematized. The problems in the Ukrainian economy that need to be eliminated in the situation of the global economic crisis are identified: high intricate taxes; lack of credit; lack of investment; under-monetisation of the economy. The number of companies operating in a falling market is shrinking faster than the market itself, sometimes much faster. Survival and customer concentration is key. The main factor of economic growth is scientific and technological progress (STP). The main mechanism for advancing economic growth is credit. The task of national banks is to lend to the real sector. The logic of our thinking: when there is sustainable economic growth in the country, then financial stability and stability of the monetary unit are achieved automatically. We proposed a mechanism for providing cheap loans to the industrial sector and a strategy of public-private partnership in Ukraine. The state has the right to create targeted loans and use state banks to direct them to finance projects necessary to modernize the economy. Control over the intended use of money - the color of money. The system can be fully automated. The money that flows in can be digitized (designated) - each bill is marked with a specific index. In the center of the strategy of economic growth should be placed the common man, his wishes and needs.

Keywords: forecast, transformation, mechanism, economy, development, problems, strategy.

Постановка проблеми. Світова економіка, починаючи із 2008 року перебуває в постійній кризі. В 2020 році кризові явища були поглиблені завдяки пандемії, особливо, впровадженню карантину. У зв'язку з цим виникає потреба дослідження прогнозу подальшого розвитку світової та вітчизняної економіки, а також пошуку механізмів розвитку економіки України в сучасних умовах.

Аналіз останніх досліджень і публікацій. Вагомий внесок щодо прогнозування та пошуку механізмів економічного зростання зробили такі зарубіжні вчені як Стендедж Т., Швабб К., Лагард К., Блонде М., експерти датського Saxo Bank.

Виділення невирішених раніше частин загальної проблеми. Незважаючи на вагомість раніше проведених досліджень, в сучасних умовах нарощування кризових явищ в економіці у зв'язку із пандемією, актуальність вирішення проблем економічного зростання та інвестиційного самозабезпечення стає надзвичайно важливими.

Формулювання цілей статті (постановка завдання). Основними завданнями статті $\epsilon$ вивчення актуальних прогнозів розвитку світової економіки, бюджету України на 2021 рік (як основного прогнозу уряду) та обґрунтування механізмів подальшого розвитку економіки України в сучасних умовах.

Виклад основного матеріалу дослідження. В кінці 2020 року датський Saxo Bank запропонував власну серію прогнозів на майбутнє із фрактичними аргументами: нова китайська цифрова валюта спровокує тектонічні зрушення в потоках капіталу (у 2019 році 80 \% всіх платежів в Китаї було здійснено електронними платежами через WeChat Pay i AliPay, Народний банк Китаю почав розширений експеримент з цифрровою валютою в жовтні 2020 року, електронний платіж стане цифрровий версією юаня на основі блокчейна); технологічна революція зробить людство енергетично незалежним (в 2021 році вдосконалений алгоритм штучного інтелекту вирішує складні завдання, відкриваючи шлях комерційної енергії синтезу, конструкція термоядерного реактора SPARC, яка була затверджена в 2020 році як шлях до дешевої енергії термоядерного синтезу, буде вдосконалена завдяки новій моделі штучного інтелекту, енергія термоядерного синтезу дозволяє майже кожній країні стати незалежною від їжі і енергії, і вона спровокує різке підвищення рівня життя); універсальний базовий дохід «знищить» мегаполіси (скорочення робочих місць, обумовлене появою нових технологій і впровадженням віддаленої роботи, можливості працевлаштування «висихають», а якість життя в маленьких квартирах із завищеними цінами втрачає свою привабливість); створення Фонду цивільних технологій (дослідники Оксорордського університету навіть прогнозують, що до 2030 року половина робочих місць в США може застаріти і зникнути, частина активів Фонду цивільних технологій отримає кожна людина, а додаткові активи отримують люди, які втратили роботу в результаті різкого технологічного прогресу); поява супутникового інтернету знизить ціни на комунікаційні послуги (Starlink від компанії SрасеX до кінця 2021 року встановить близько 1500 супутників) [1].

Журнал The Economist перераховує тенденції, за якими варто стежити в наступному році: змішане економічне відновлення (уряди зроблять розворот від підтримки «життєдіяльності» компаній до спроб допомогти працівникам, які втратили роботу); напруга між США і Китаєм посилиться (багато країн: від Афррики до Південно-Східної Азії, - намагаються з усіх сил, щоб не стати на чийсь бік у цій війні на тлі зростання напруги); бізнес все більше стає геополітичним полем бою (боси компаній мають справу не тільки 3 тиском «зверху», але і «знизу», оскільки працівники та клієнти вимагають переходу на стандарти, які б допомогли боротися зі змінами клімату і за встановлення соціальної справедливості); зміна поведінки людей 
під впливом технологій (від відео-конференцій до покупок в Інтернеті і віддаленої роботи або навчання); світ більше не буде таким відкритим, як раніше (туризм скоротиться і зміниться, авіакомпанії, мережі готелів і виробники літаків постраждають, так само як і університети, які сильно залежать від іноземних студентів, культурний обмін скоротиться) [2].

Газета Financial Times пише про п'ять сил, які визначать майбутнє людства після пандемії. Перша 3 них - технології (люди зможуть (i їм дозволять) працювати за межами офрісу, неминуче це зачепить не лише тих, хто працює в рідних країнах, а й кадри, найняті за кордоном за менші зарплати, в результаті, з'явиться дестабілізуючий фрактор під назвою «віртуальна міграція»). Друга сила - це нерівність (багато високооплачуваних офрісних працівників зможуть виконувати свої обов'язки з дому, але більшість інших - ні). Третя сила - борги (згідно 3 оцінками Інституту міжнародних фрінансів, глобальна валова заборгованість підскочило 3 і без того високого показника на рівні $321 \%$ від світового ВВП в 2019 році до $362 \%$ станом на кінець червня 2020-го, такий величезний і раптовий стрибок ніколи ще не відбувався у мирні часи). Четвертий фрактор - деглобалізація (була підписана угода про Регіональне всеосяжне економічне партнерство, яка об'єднала 10 країн Асоціації держав Південно-Східної Азії з Австралією, Китаєм, Японією, Новою Зеландією й Південною Кореєю). П'ята сила, яка визначить майбутнє - це політичні конфолікти (зростання напруги між США і Китаєм, інші країни будуть змушені стати на бік когось 3 них) [3].

Клаус Швабб, німецький економіст; засновник і беззмінний президент Всесвітнього економічного фроруму в Давосі з 1971 року, творець спільноти «Global Shapers Community», викладач ділового адміністрування в Женевському університеті, написав книгу «Глобальне ковідне перезавантаження» [5]. Він дає свій прогноз на майбутнє національних держав: «Нездатність урядів національних держав поборотися 3 глибоко вкоріненими хворобами наших суспільств і економік зміцнить ризик - як це було протягом всієї історії - що рецидив хвороби спричинить за собою сильні потрясіння, конфлікти і навіть революції. Пандемія дає нам цей шанс: це вузьке вікно можливостей для роздумів, рішень і перезавантаження нашого світу. Якщо демократія і глобалізація будуть розширюватися, то національній державі місця не залишиться. Все вирішуватимуть нікому не підзвітні групи експертів, і не тільки по частині медицини.
А за ними повинні стояти глобальні корпорації з соціальною відповідальністю...». Таким чином, поважний німецький економіст говорить про повне перезавантаження світу.

Мауріціо Блонде, італьянський католицький викладач та публіцист, пише, що «Папа Франциск оголосив, що Ватикан вступить в «глобальний альянс» 3 найбільшими світовими банками, міжнародними корпораціями і глобалістськими фондами для створення економічної ради, спрямованого на перерозподіл багатства по всьому світу. Глобалістська ініціатива, іменована «Рада з інклюзивної капіталізму», називає себе прокапіталістичною організацією, метою якої є створення «більш сильних, справедливих і спільних економік і суспільств» [6].

В свою чергу, Європейський Центральний Банк (ЄЦБ), хоче, щоб євро залишався придатним для цифрової епохи. На початку цього року Рада керуючих вирішив вивчити можливість випуску цифррового євро - іншими словами, циоррових грошей центрального банку для роздрібних платежів [4].

В 2020 році мережею Інтернет поширився огляд цифрової трансфрормації Microsoft CEE 2020 «Ключові галузі еволюції. Як інтелектуальні технології змінюють роздрібну торгівлю, виробництво і фрінанси в Центральній і Східній Європі» [11]. Інфрормація вищеназваного огляду слід вважати актуальною для подальшої трансорормації економіки України.

Виходячи із матеріалів огляду щодо використання штучного інтелекту (передового напрямку сучасних нових технологій): 66 \% рітейлерів Центрально-Східної Європи або використовують штучний інтелект вже зараз або ж планують це робити починаючи з наступного року; $63 \%$ виробників Центральної та Східної Європи в даний час використовують передові технології, такі як штучний інтелект, або будуть робити це в період наступних 12 місяців; $25 \%$ організацій орінансових послуг в регіоні вже використовують штучний інтелект для оптимізації своїх бізнесів, а $43 \%$ фрінансових компаній вважають, що на основі штучного інтелекту цільовий маркетинг стане пріоритетом.

Відносно розвитку штучного інтелекту в Україні: уряд затвердив концепцію розвитку штучного інтелекту в Україні до 2030 року. Основні напрямки Концепції включають: удосконалення середньої, вищої освіти та підвищення кваліфрікації з метою підготовки кваліфрікованих фрахівців у ссрері штучного інтелекту; стимулювання наукових досліджень у галузі, зокрема за допомогою грантів; стимулювання підприємництва у галузі штучного 
інтелекту, а також розробка методу перекваліфрікації кадрів, що можуть втратити роботу через автоматизацію за 5-10 років; робота 3 підвищенням рівня кібербезпеки, удосконалення законодавства у сфрері кіберзахисту; застосування технологій штучного інтелекту в оборонній ссрері та публічному управлінні; розв'язання проблем роботи держреєстрів; використання штучного інтелекту у правосудді, зокрема для попередження небезпечних явищ завдяки аналізу наявних даних [12].

Аналізуючи дану концепцію, слід наголосити, що в ній відсутня допомога уряду щодо впровадження штучного інтелекту в основних галузях економіки, таких як рітейл, виробництво та фрінанси, що можливо допомогло українським підприємствам даних галузей стати конкурентоспроможними за рахунок кращого менеджменту та маркетингу.

Нові виклики диктують нову реальність для підприємств основних галузей економіки України. В даному аспекті все залежить від якості української еліт, які приймають рішення та прогнозують майбутнє. Індекс якості еліт (Elite Quality Index) - дослідницький проект міжнародної програми Університету Санкт-Галлена, який вимірює показник якості еліт в країнах світу. Лідером рейтингу є Сінгапур - 68,5 бала. Далі за ним слідують європейські країни - Швейцарія $(64,9$ бала), Німеччина $(64,2)$ і Великобританія $(63,9)$. На п'ятій сходинці знаходиться США
(63,4 бала). Україна, на жаль, серед перших 32-х країн не представлена [13].

В грудні 2021 року був прийнятий Верховною Радою України бюджет. До бюджету України на 2021 рік заклали: доходи 1092 млрд. грн; витрати - 1347 млрд. грн; десріцит - 246,6 млрд. грн; зростання ВВП на рівні 4,6 \%; споживча інсрляція на рівні 7,3 \%; курс долара - 29,1 грн. за долар; зростання мінімальної заробітної плати 31 січня 2021 року становитиме 6000 грн., 31 грудня 2021 - 6500; прожитковий мінімум на одну людину в місяць: 31 січня - 2189 гривень, 31 липня - 2294 грн., 31 грудня - 2393 грн; середню зарплату очікують на рівні 13632 гривень на місяць, а безробіття в $9,2 \%$ [7].

Як бачимо із таблиці 1 , за період 2014-2021 рр. найбільше зниження в структурі видатків бюджету відбулося в міжбюджетних транссрертах, що пов'язано з процесом децентралізації. Сутність міжбюджетних трансорертів в тому, що це кошти, які безоплатно і безповоротно передаються з одного бюджету до іншого. Видаткова частина в гривні збільшилась за досліджуваний період в 3,1 рази, а курс долара - в 3,4 рази, що призвело до того, що видаткова частина зменшилась на 5 млрд. дол., що для України представляє значними коштами.

Так, якщо вірити зазначеним в презентації бюджету даними, 439,3 мільярда гри-

Структура видаткової частини Державного бюджету України (2014-2021 рр.), \%

\begin{tabular}{|l|c|c|c|}
\hline & $\mathbf{2 0 1 4}$ & $\mathbf{2 0 2 1}$ & $\mathbf{2 0 2 1}$ до 2014 (+-) \\
\hline Міжбюджетні трансоерти & 30,3 & 1,8 & $-28,5$ \\
\hline $\begin{array}{l}\text { Соціальний захист } \\
\text { та соціальне забезпечення }\end{array}$ & 18,7 & 24,0 & $+5,3$ \\
\hline Обслуговування боргу & 11,2 & 12,0 & $+0,8$ \\
\hline $\begin{array}{l}\text { Громадський порядок, безпека } \\
\text { та судова влада }\end{array}$ & 10,4 & 12,1 & $+1,7$ \\
\hline Економічна діяльність & 8,0 & 10,5 & $+2,5$ \\
\hline Освіта & 6,7 & 12,8 & $+6,1$ \\
\hline Оборона & 6,4 & 8,8 & $+2,4$ \\
\hline Загальнодержавні фрункції & 4,1 & 4,3 & $+0,2$ \\
\hline Охорона здоров'я & 2,5 & 11,5 & $+9,0$ \\
\hline Духовний та фрізичний розвиток & 1,1 & 1,3 & $+0,2$ \\
\hline $\begin{array}{l}\text { Охорона навколишнього } \\
\text { природного середовища }\end{array}$ & 0,6 & 0,6 & - \\
\hline Житлово-комунальне господарство & 0,03 & 0,3 & $+0,27$ \\
\hline Всього & 100,0 & 100,0 & - \\
\hline Видаткова частина, трлн. грн. & 0,430 & 1,328 & 3,1 рази більше \\
\hline Курс долара & $8,5 / 1$ \$ & $29,1 / 1$ \$ & 3,4 рази більше \\
\hline Видаткова частина, трлн. дол. & 0,0506 & 0,0456 & Менше на 5 млрд. дол. \\
\hline
\end{tabular}


вень піде на погашення державного боргу, 160,5 мільярда гривень - на його обслуговування. Виплати розподіляються наступним чином: 2,4 мільярда гривень - виплати за осріційними позиками; 43,8 мільярда гривень виплати за позиками міжнародних фрінансових організацій; 112,3 мільярда гривень - виплати за комерційними позиками; 112 мільярдів гривень - виплати за облігаціями державної позики в іноземній валюті; 328,6 мільярда гривень - виплати по облігаціям внутрішніх державних позик (ОВДП) у гривні [8].

Адам Сміт [14], шотландський економіст, один 3 основоположників сучасної економічної теорії написав у другій половині XVIII століття, що якщо $€$ замкнута економічна система, то вона розвивається до своїх потенційних розмірів, а потім зупиняється.

Перспективи розвитку економічної системи в світі пов'язано зі зміною технологічних укладів, які $є$ сукупністю технологій і виробництв одного рівня. У 1920-ті роки Микола Кондратьєв описав в своїх роботах періодичні цикли (тривалістю 48-55 років), які змінюються підйомами і спадами світової економіки. Йозеф Шумпетер у 1939 році у своїй книзі «Ділові цикли» підтримав і розвинув закономірність, виявлену Кондратьєвим.

У своїй роботі «Теорія довгострокового техніко-економічного розвитку» [15] Глазьєв С.Ю. пише, що в другому десятилітті XXI століття сорормується відтворювальних система шостого технологічного укладу. Ключові напрямки його розвитку: біотехнології, засновані на досягненнях молекулярної біології та генної інженерії, нанотехнології, системи штучного інтелекту, глобальні інформаційні мережі та інтегровані високошвидкісні транспортні системи. На сьогоднішній день в розвинених країнах домінують технології п'ятого укладу (ключовим фрактором $€$ мікроелектроніка та програмне забезпечення) і фрормуються технології шостого технологічного укладу.

У світі відбувається економічна криза. Чи можна нормально фрункціонувати в умовах спаду? Всі великі статки робилися не в умовах економічного зростання, а в умовах спаду. Кількість компаній, що працюють на ринку, що падає скорочується швидше, ніж сам ринок, іноді сильно швидше. Висновок наступний: клієнти конкурентів прийдуть до вас. Чим довше живете на падаючому ринку, тим більше виграєте. Тобто, компанії стають більше, ніж були на зростаючому ринку, але кількість компаній скорочується. Ключовий момент - виживання і концентрація клієнтів.
Які існують проблеми в українській економіці, що вимагають усунення в ситуації світової економічної кризи: високі заплутані податки; відсутність кредитування; відсутність інвестицій; недомонетизація економіки. Усунувши вищеназвані проблеми ми отримаємо економічне зростання.

Правова основа вже існує, так в Конституції України [16] є стаття 99: «Грошовою одиницею України є гривня. Забезпечення стабільності грошової одиниці $€$ основною орункцією центрального банку держави - Національного банку України». Далі, в Законі України Про Національний банк України [17] існує стаття 6. Основна фрункція: «Відповідно до Конституції України основною фуункцією Національного банку $€$ забезпечення стабільності грошової одиниці України. Національний банк у межах своїх повноважень сприяє фрінансовій стабільності, в тому числі стабільності банківської системи за умови, що це не перешкоджає досягненню цілі, визначеної у частині другій цієї статті. Національний банк також сприяє додержанню стійких темпів економічного зростання та підтримує економічну політику Кабінету Міністрів України за умови, що це не перешкоджає досягненню цілей, визначених у частинах другій та третій цієї статті».

Наведемо висловлювання сучасних фрінансових та політичних лідерів, так, Джанет Йеллен, колишня голова Федеральної резервної системи наголосила: «Федеральна резервна система відповідальна за створення сприятливих умов для максимальної зайнятості, збереження низької і стабільної інфляції, а також безпечної та ефрективної фрінансової системи» [18, с. 210]. Реджеп Тайіп Ердоган, президент Туреччини: «Чим більше підвищує Центральний банк Туреччини ключову ставку, тим більше в країні інфрляція» [19].

Що президент Туреччини має на увазі? В економіці підприємства ключовий показник - собівартість продукції. Чим вищий відсоток по кредитах, тим вища собівартість продукції, а отже і інфрляція.

Виходячи із вищезазначеного, пропонуємо змінити пріоритети. На перше місце серед фрункцій НБУ слід поставити - «сприяє додержанню стійких темпів економічного зростання». На друге місце - «сприяє фрінансовій стабільності, В тому числі стабільності банківської системи». На третє місце - «забезпечення стабільності грошової одиниці України».

Логіка наших роздумів: коли буде стійке економічне зростання в країні, тоді фрінансова стабільність та стабільність грошової одиниці досягаються автоматично. 
Для того, щоб комплекс нових технологій з'явився на ринку і став драйвером економіки, потрібен фрактор, який ініціює імпульс - дешевий кредит. Головний фрактор економічного зростання - науково-технічний прогрес (НТП). Головний механізм авансування економічного зростання - це кредит. Завдання національних банків - кредитувати реальний сектор. Потрібні банки, які займаються виробничими інвестиціями. Оцінювати банки потрібно не за обсягом прибутку, а за обсягом інвестицій.

Держава має право створювати цільові кредити і через державні банки направляти їх на фрінансування проектів, потрібних для модернізації економіки. Створювати індикативні плани нарощування інвестицій в такі напрямки підйому реального сектора.

Контроль за цільовим використанням грошей - забарвленість грошей. Можна систему повністю автоматизувати. Гроші, які вливаються можна оцифрувати (позначити) - кожну купюру мітити певним індексом. В Японії пішли таким шляхом (систему держзакупівель переводять в цифрру). Банк Китаю вводить цифрровий юань як базовий елемент грошового обігу.

Висновки. Практикою доведено, щоб забезпечити $10 \%$ економічне зростання ВВПпотрібно на $20 \%$ піднімати зростання інвестицій. Один мудрий чоловік сказав: «Якщо людина готова віддати життя за свою державу - то це держава рано чи пізно буде процвітати». В центрі стратегії економічного зростання слід ставити просту людину, українця, його бажання і потреби. Буде задоволений пересічний українець, тоді буде задоволена держава.

Пропонуємо Стратегію приватно-державного партнерства, яка включає: стратегічне планування держави розвитку конкурентоспроможних галузей, в яких бізнес бачить пріоритети для себе; індикативне планування (кінцеві показники); інвестиційні контракти та їх фрінансування через НБУ та комерційні банки.

\section{СПИСОК ВИКОРИСТАНИХ ДЖЕРЕЛ:}

1. 10 outlandish forecasts for 2021. Saxo Bank. URL: https://www.home.saxo/insights/news-and-research/ thought-leadership/outrageous -predictions (дата звернення: 15.12.2020).

2. Standage T. Ten trends to watch in the coming year. The Economist. URL: https://www.economist.com/ the-world-ahead/2020/11/16/ten-trends-to-watch-in-the-coming-year (дата звернення: 16.12.2020).

3. Five forces that will define our post-Covid future. Financial Times. URL: https://www.ft.com/content/dd359 338-6200-40d3-8427-901bad134е21 (дата звернення: 16.12.2020).

4. Lagarde C. The future of money - innovating while retaining trust. European Central Bank. Eurosystem. URL: https://nww.ecb.europa.eu/press/inter/date/2020/htm//ecb.in201130 ce64cb35a3.en.html (дата звернення: 17.12.2020).

5. Швабб К. Глобальная ковидная перезагрузка. Иностранные CMИ. URL: https://inosmi.ru/economic/ 20201122/248589367.html (дата звернення: 17.12.2020).

6. Blondet M. II Vaticano entra in "Alleanza globale" con Rothschild, Fondazione Rockefeller e grandi banche per creare un Great Reset. Blondet \& Friends. URL: https://www.maurizioblondet.it/il-vaticano-entra-in-alleanza-globalecon-rothschild-fondazione-rockefeller-e-grandi-banche-per-creare-un-great-reset (дата звернення: 17.12.2020).

7. Онищенко В. Державний бюджет 2021. MCFR. Медіагрупа і мережа профресійних сайтів. URL: https://www.golovbukh.ua/article/8484-derjavniy-byudjet-na-2021-rk (дата звернення: 18.12.2020).

8. Украина выплатит в 2021 году полтриллиона гривен по госдолгу. Деньги.UA. URL: https://dengi.ua/ finance/2240799-ukraina-vyplatit-v-2021-godu-poltrilliona-griven-po-gosdolgu (дата звернення: 18.12.2020).

9. Статистичний збірник: «Бюджет України 2014». Міністерство фінансів України. Офіційний веб-портал. URL: https://mof.gov.ua/uk/statistichnij-zbirnik (дата звернення: 19.12.2020).

10. Проект Закону про Державний бюджет України на 2021 рік. Верховна Рада України. Офріційний вебпортал. URL: https://w1.c1.rada.gov.ua/pls/zweb2/webproc4_1?pf3511=69938 (дата звернення: 19.12.2020).

11. Миронова Н. Галузі майбутнього: штучний інтелект. Mind. URL: https://mind.ua/publications/20187132galuzi-majbutnogo-shtuchnij-intelekt (дата звернення: 20.12.2020).

12. Ключевые отрасли эволюции. Как интеллектуальные технологии меняют розничную торговлю, производство и фринансы в Центральной и Восточной Европе. Український Інститут політики. URL: https://uiamp.org.ua/klyuchevyeotrasli-evolyucii-kak-intellektualnye-tehnologii-menyayut-roznichnuyu-torgovlyu (дата звернення: 20.12.2020).

13. Рейтинг стран мира по индексу качества элит. Гуманитарный портал. URL: https://gtmarket.ru/ratings/ elite-quality-index (дата звернення: 20.12.2020).

14. Смит А. Исследование о природе и причинах богатства народов. Москва : Эксмо, 2017. 1056 с.

15. Глазьев С.Ю. Теория долгосрочного технико-экономического развития. Москва : ВлаДар, 1993. 310 с.

16. Конституція України. Президент України. Офіційне інтернет-представництво. URL: https://www.president.gov.ua/ documents/constitution (дата звернення: 21.12.2020). 
17.Закон України Про Національний банк України. Верховна Рада України. URL: https://zakon.rada.gov.ua/ laws/show/679-14\#Text (дата звернення: 21.12.2020).

18. Воронцова Ю. Банкиры, которые изменили мир. Москва : Манн, Иванов и Фербер, 2015. 248 с.

19. Шаталин В. Центробанк Турции резко повысил процентную ставку. DW. URL: https://www.dw.com/ru/ а-45480387 (дата звернення: 22.12.2020).

\section{REFERENCES:}

1. Saxo Bank (2020) 10 outlandish forecasts for 2021. Retrieved December 15, 2020. Retrieved from: https://www.home.saxo/insights/news-and-research/thought-leadership/outrageous-predictions

2. Standage T. (2020) Ten trends to watch in the coming year. The Economist. Retrieved December 16, 2020. Retrieved from: https://www.economist.com/the-world-ahead/2020/11/16/ten-trends-to-watch-in-the-coming-year

3. Financial Times (2020) Five forces that will define our post-Covid future. Retrieved December 16, 2020. Retrieved from: https://www.ft.com/content/dd359338-6200-40d3-8427-901bad134e21

4. Lagarde C. (2020) The future of money - innovating while retaining trust. European Central Bank. Eurosystem. Retrieved December 17, 2020. Available at: https://www.ecb.europa.eu/press/inter/date/2020/html/ecb. in201130 ce64cb35a3.en.html

5. Shvabb K. (2020) Global'naya kovidnaya perezagruzka [Global covid reboot]. Inostrannye SMI. Available at: https://inosmi.ru/economic/20201122/248589367.html (accessed 17 December 2020).

6. Blondet M. (2020) II Vaticano entra in "Alleanza globale" con Rothschild, Fondazione Rockefeller e grandi banche per creare un Great Reset [The Vatican enters into a "Global Alliance" with Rothschild, the Rockefeller Foundation and major banks to create a Great Rese]. Blondet \& Friends. Retrieved December 17, 2020. Available at: https://www.maurizioblondet.it/il-vaticano-entra-in-alleanza-globale-con-rothschild-fondazione-rockefeller-e-grandibanche-per-creare-un-great-reset

7. Onyshchenko V. (2020) Derzhavnyi biudzhet 2021 [State budget 2021]. MCFR. Mediahrupa i merezha profesiinykh saitiv. Available at: https://www.golovbukh.ua/article/8484-derjavniy-byudjet-na-2021-rk (accessed 18 December 2020).

8. Den'gi.UA (2020) Ukraina vyplatit $v 2021$ godu poltrilliona griven po gosdolgu [Ukraine will pay half a trillion hryvnia in 2021 on the state debt]. Available at: https://dengi.ua/finance/2240799-ukraina-vyplatit-v-2021-godu-poltrilliona-griven-po-gosdolgu (accessed 18 December 2020).

9. Ministerstvo finansiv Ukrainy. Ofitsiinyi veb-portal (2015) Statystychnyi zbirnyk: «Biudzhet Ukrainy 2014» [Statistical collection: "Budget of Ukraine 2014"]. Available at: https://mof.gov.ua/uk/statistichnij-zbirnik (accessed 19 December 2020).

10. Verkhovna Rada Ukrainy. Ofitsiinyi veb-portal. Proekt Zakonu pro Derzhavnyi biudzhet Ukrainy na 2021 rik [Draft Law on the State Budget of Ukraine for 2021]. Available at: https://w1.c1.rada.gov.ua/pls/zweb2/webproc4_1?pf3511=69938 (accessed 19 December 2020).

11. Myronova N. (2020) Haluzi maibutnoho: shtuchnyi intelekt [Areas of the future: artificial intelligence]. Mind. Available at: https://mind.ua/publications/20187132-galuzi-majbutnogo-shtuchnij-intelekt (accessed 20 December 2020).

12. Ukrainskyi Instytut polityky (2020) Klyuchevye otrasli evolyutsii. Kak intellektual'nye tekhnologii menyayut roznichnuyu torgovlyu, proizvodstvo i finansy $v$ Tsentral'noy i Vostochnoy Evrope [Key branches of evolution. How smart technology is changing retail, manufacturing and finance in Central and Eastern Europe]. Available at: https://uiamp.org.ua/klyuchevye-otrasli-evolyucii-kak-intellektualnye-tehnologii-menyayut-roznichnuyu-torgovlyu (accessed 20 December 2020).

13. Gumanitarnyy portal (2020) Reyting stran mira po indeksu kachestva elit [Rating of countries in the world according to the quality index of elites]. Available at: https://gtmarket.ru/ratings/elite-quality-index (accessed 20 December 2020).

14. Smit A. (2017) Issledovanie o prirode i prichinakh bogatstva narodov [Research on the nature and causes of the wealth of nations]. Moskva: Eksmo, 1056 p. (in Russian)

15. Glaz'ev S.Y. (1993) Teoriya dolgosrochnogo tekhniko-ekonomicheskogo razvitiya [The theory of long-term technical and economic development]. Moskva: VlaDar, 310 p. (in Russian)

16. Prezydent Ukrainy. Ofitsiine internet-predstavnytstvo (2019) Konstytutsiia Ukrainy [Constitution of Ukraine]. Available at: https://www.president.gov.ua/documents/constitution (accessed 21 December 2020).

17. Verkhovna Rada Ukrainy (2020) Zakon Ukrainy Pro Natsionalnyi bank Ukrainy [Law of Ukraine On the National Bank of Ukraine]. Available at: https://zakon.rada.gov.ua/laws/show/679-14\#Text (accessed 21 December 2020).

18. Vorontsova Y. (2015) Bankiry, kotorye izmenili mir [Bankers who changed the world]. Moskva: Mann, Ivanov i Ferber, 248 p. (in Russian)

19. Shatalin V. (2018) Tsentrobank Turtsii rezko povysil protsentnuyu stavku [Turkey's central bank raises interest rates sharply]. DW. Available at: https://www.dw.com/ru /a-45480387 (accessed 22 December 2020). 